Article

\title{
Circular Economy and E-Waste: An Opportunity from RFID TAGs
}

\author{
Alessia Condemi, Federica Cucchiella * (D) and Domenico Schettini \\ Department of Industrial and Information Engineering and Economics, University of L'Aquila, \\ Via G. Gronchi n. 18, 67100 L'Aquila, Italy \\ * Correspondence: federica.cucchiella@univaq.it
}

Received: 1 July 2019; Accepted: 15 August 2019; Published: 19 August 2019

\begin{abstract}
In this work, a deep economic and technical analysis for the enhancement of e-waste hierarchy applied to the Radio Frequency Identification (RFID) tags is presented. Nowadays, the RFID technology represents a valuable solution for many applications to improve the quality and efficiency of the supply chain, as well as for enhanced people or object identification and smart devices. This leads to massive usage of such devices that could represent a threat to the environment, since they are often considered as generic waste and no specific e-waste policy has been identified for RFID. For these reasons, the paper presents a study based on the desk research technique to propose several possibilities currently available for producers of different RFID devices in order to mitigate this problem at every e-waste hierarchy stage, i.e., ecological design and prevention, reuse, recycle, and disposal. Moreover, a cost/benefit analysis has been reported in order to highlight the economic advantages related to the RFID tags reuse, as well as environmental impact reduction. Results proved that passive RFID tags represent the major candidate for the e-waste hierarchy enhancement at every level, demonstrating that it is more convenient for the producer to consider an ecologically aware design and promote a take-back system for tags in order to take advantages from the solution proposed for the RFID e-waste hierarchy.
\end{abstract}

Keywords: e-waste; RFID tags; extended producer responsibility (EPR), environment; circular economy; WEEE; recycle and reuse

\section{Introduction}

Since communication with products must take place in a simple, economically convenient way at all times and throughout the production and laboring process, automatic identification systems are an important part of the entire production chain [1]. By exploiting recent technological developments, it is possible to overcome or prevent problems and dysfunctions that are economically onerous to production costs, such as verification of the correct composition of the assembled pieces, checking the processing times and methods, strengthening the safety of workers, monitoring the state of health of the machines in terms of energy-saving [2], and optimizing maintenance cycles [3]. Also, the improvement of the yield and the qualitative profile of the manufactured product is one of the reasons supporting production traceability [4]. Having a continuous and truthful perception of the various departments and the progress of every single piece, providing the information in real time not only to the production process, but also to a correct and punctual order fulfilment and, therefore, customer satisfaction, is part of a lean approach to production, especially in the textile and agri-food sector [5]. The possibility of identifying, selecting, and managing the resulting data is fundamental in order to make the flow of information coherent and truly usable, which is one of the critical resources of manufacturing [6]. In this scenario, one of the valuable and most diffused technologies that are employed to enhance the production chain is the Radio Frequency Identification (RFID) system. 
RFID technology is an automated identification system mainly based on the RF microwave transmission and is considered the natural evolution of traditional identification systems, such as bar codes, magnetic cards, and smart cards. Although its theory of operation was conceived with the beginning of radio frequency communications era, the usage of RFID systems is nowadays constantly increasing, thanks to the continuous technological advances that enabled such devices to be one of the key parts for a novel human scenario of smart communication, like the recent IoT (Internet of Things) applications.

Broadly speaking, RFID technology includes a vast set of microdevices that are used to identify various product categories, such as electronic toll collection systems, labels implanted in animals for their identification, access control—tickets and cards—-for which the proximity reading is used without physical or visual contact, and the centralized locking systems for motor vehicles. The RFID TAGs are also integrated into clothing tags or shoes, and an Italian company has recently patented a stopper for wine bottles [7]. RFID functions are also integrated into passports, health cards, and even banknotes. In Italy, since the end of October 2006, passports have been issued with an integrated RFID compliant with the ISO 14,443 Smart Card standard [8]. The decree of the Italian Ministry of Foreign Affairs of 29 November 2005 provides that in the TAG memory of at least $64 \mathrm{~Kb}$, information concerning the passport and the holder, as well as the computer codes for protection and inalterability, even the photographic image of the face and the fingerprints of the index finger of each hand, should be stored.

One class of applications in which the use of RFID is becoming pervasive is that related to the supply chain of goods $[9,10]$. In this regard, since 2005, the European Parliament has launched legislation that makes the traceability of assets along the distribution chain mandatory. This has favored the development of RFIDs that lend themselves much better than traditional barcodes to convey information about objects and transfer them to the systems that interrogate them. In this sense, RFIDs are used in the distribution chain mainly as a support for the universal identifier codes of EPC (Electronic Product Code) objects.

Recently, the use of RFID technology in the area of recycling also became a reality [11]. In Italy, the adoption of this technological solution stems from the need to trace the different types of waste produced in a reliable and automatic way, associating them with the user in compliance with the regulatory framework outlined by the law. In fact, the national legislation sets precise objectives for separate collection (article 205 of Legislative Decree 152/06 and article 1, paragraph 1108, of Law 296/2006-Financial Law 2007). The starting point for meeting these requirements is to have reliable data about the collected waste (first of all, the type of waste and the user) without interfering in the usual operational process of the picking workers, therefore a user-friendly and robust solution, whose advantages lie in the possibility of fair taxation in addition to the control and waste management. The most advanced regions in this sense are Puglia, Abruzzo, Emilia-Romagna, and Tuscany, with the best performance [12], which mostly use systems aimed at identifying the single garbage bag to better rationalize services and penalize those who produce larger quantities of waste. This legislation, known as SISTRI—the acronym of "Sistema di Controllo della Tracciabilità dei Rifiuti" or "Waste Traceability Control System", in English—wanted by the national legislator and originally provided by Law n. 296 and by Legislative Decree 4/2008 and introduced in December 2009 (ministerial decree 17 December 2009) with the dual purpose of combating illicit traffic and illegal waste disposal and to simplify the documentary requirements for businesses, has been deleted pursuant to art. 6 of the law of 14 December 2018, n. 135. In other words, the use of RFID TAGs is "additional" and not a substitute for affixing the Register number to the product.

The date of departure of such a system will be put into operation by the end of 2020, according to gradual criteria for the progressive participation of all operators [13]. Therefore, it can be stated that a large and increasing amount of RFID devices will be certainly employed in the next future in order to enhance waste traceability.

In the meantime, some Italian companies dealing with waste management and disposal have already equipped themselves with RFID systems like other European countries, including neighboring 
Spain [11]. As an example, in Lucca, Italy, the Sistema Ambiente s.p.a. company has equipped the home waste containers with specific identification tags and installed RFID devices onboard the vehicles in order to know the exact number of withdrawals of waste generated by each user (Figure 1), thus providing the necessary data for the calculation of punctual pricing according to the Pay What you Throw principle $[14,15]$. In this way, the user is encouraged to select recyclable materials, so as to minimize the amount of residual waste to be disposed of and, therefore, contain the related taxation, all at a low cost of workers for the Sistema Ambiente company.

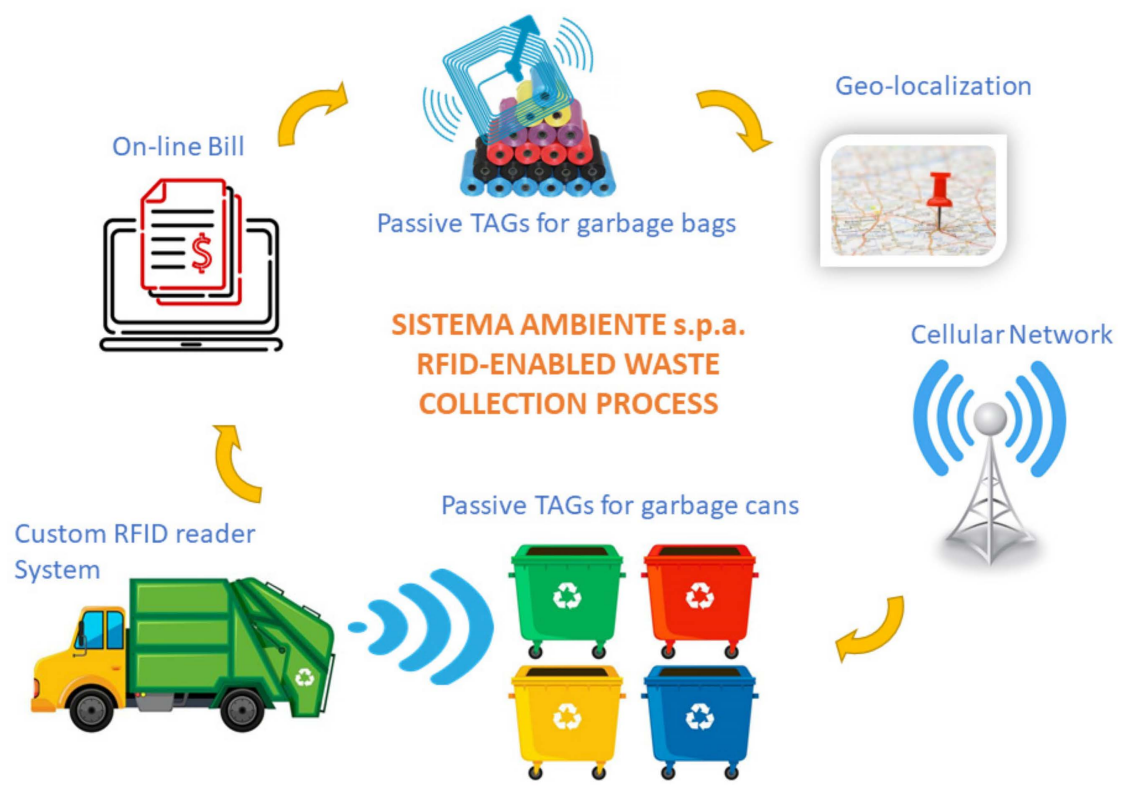

Figure 1. The waste collection cycle carried out by Sistema Ambiente s.p.a. company in Lucca, Italy.

The starting point of an eco-sustainable and virtuous system of waste management is, therefore, the responsibility of the citizen, who must correctly differentiate the waste already produced at home, dividing it into special and equally different containers [16].

In this perspective of such massive usage of this RFID technology, despite the many advantages, it can represent a concerning environmental impact $[17,18]$. In fact, the reduced dimensions of RFID tags must be considered as e-waste when they reach their end-of-life, as is the case for all information and communications technologies (ICT) in which the RFID system is included [19]. Moreover, the TAG life-cycle often exceeds the average duration of the objects they are associated with, especially the passive TAGs, which do not require batteries and have a theoretically infinite life expectancy [8]. This ends up in the paradox that the tags, also used for waste management in an environmentally sustainable perspective, are themselves contaminants.

This is even more evident in the textile industry where tags are used to identify clothing with anti-shoplifting functions and are commonly known as intelligent labels. They are also employed for identification in the secondhand clothing business, where utilized textiles are either endorsed to a separate gathering of used clothes or discarded [20]. These RFID textile tags are so well-integrated into clothes that consumers are often not even aware of their presence and, therefore, they are destinated to the general civil waste collector.

To date, the problem of RFID as e-waste is not considered by the majority of the populations, since the tags are very small and the effect they may have on the environment is not perceived. Thus, they are not discarded following the correct electronic waste treatment channel and they are lost in the flow of generic wastes. For these reasons, data are not available specifically related to the production of RFID waste. However, it is possible to estimate the problem by analyzing the growth trend of generic e-waste globally produced in recent years, as reported by the United Nations University (UNU) [21] and depicted in Figure 2. 


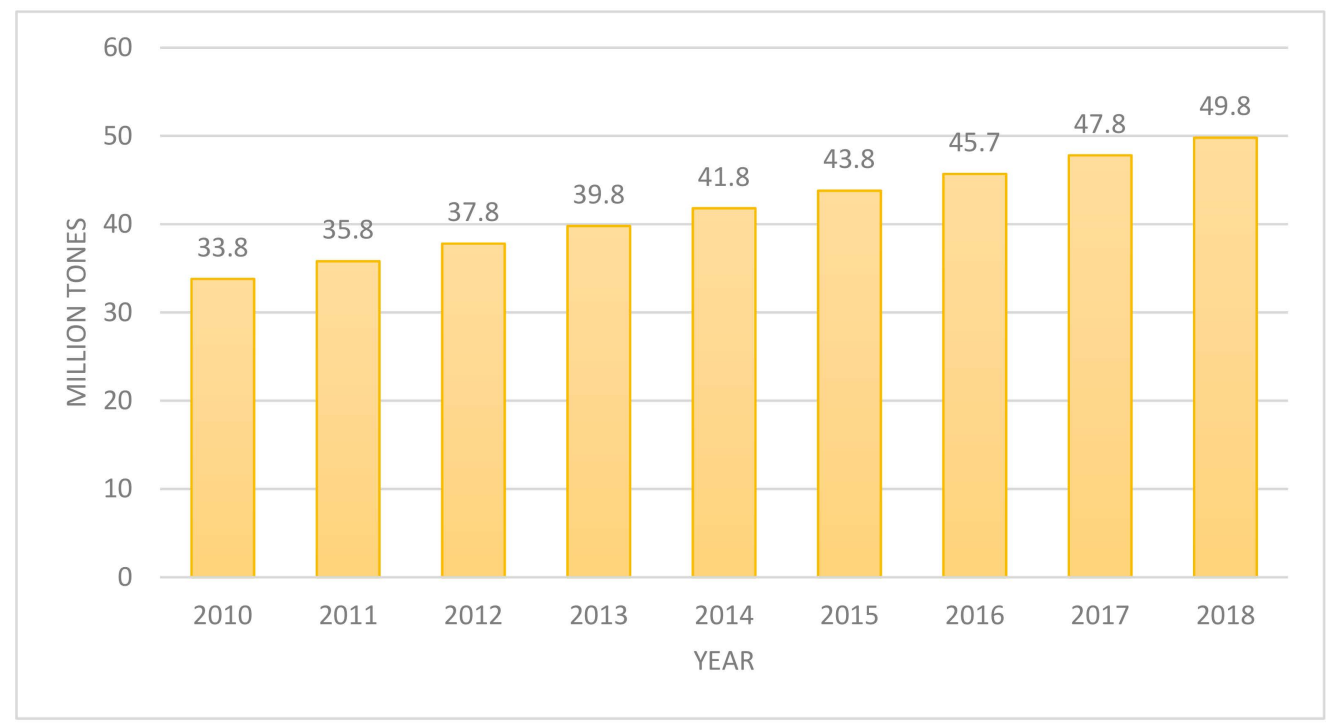

Figure 2. The trend of e-waste quantity produced in recent years globally.

Clearly, one of the causes related to this problem is bad education and sensibilization of citizens. On the other hand, electronic equipment producers are also responsible for e-waste environmental impact, in terms of inconspicuous design, usage of toxic material or difficulty to treat, and the recent trend to incentivize purchasing new products, rather than repairing for the reuse, as it is more profitable for the company from an economic point of view.

To mitigate this problem, in the last years, the concept of Extended Producer Responsibility (EPR) has been introduced globally by national regulations. The Extended Producer Responsibility is the principle or policy tool that the producer of a given product cannot lose interest, but on the contrary, must take care, even of the end of life of a product. The EPR is considered one of the main policy instruments in waste management that supports the implementation of the European waste hierarchy: The EPR is defined as a principle of environmental policy in which the responsibility of the producer is extended to the post-consumption phase of product life-cycle, including the withdrawal, recycling, and final disposal [22]. In particular, according to the Organization for Economic Co-operation and Development (OECD), the "Extended Producer Responsibility (EPR) is a policy approach under which producers are given a significant responsibility—financial and/or physical—for the treatment or disposal of post-consumer products." In addition, "Assigning such responsibility could in principle provide incentives to prevent wastes at the source, promote product design for the environment and support the achievement of public recycling and materials management goals" [23].

The goal is to ensure that producers internalize the environmental costs generated at the end of their lives by their products (for collection, selection, landfill, waste-to-energy, or recycling), thus encouraging them to opt for more virtuous products that, at the end of their life, can generate lower costs as they can be re-used (in whole or in part) or recycled.

The EPR, based on specific European and National Regulations such as the one on the Management of Waste of Electric and Electronic Equipment (WEEE), is one of the market instruments used to protect the environment, precisely aiming to modify the operators' economic behavior upstream (and consumers). The EPR is intimately connected to the additional cardinal principle in environmental and waste matters, known as the Polluter Pays Principle, which sets up a form of objective liability for the polluter [24].

At the regulatory level and in terms of general discipline, the EPR is crystallized in European law and in art. Provision 8 of the Waste Framework Directive 2008/9818 [25], a rather generic provision is, in fact, confined to the decision of the Member States to decide whether or not to introduce the EPR ("may adopt"), and in this case, in what form (merely financial, or even organizational responsibility, for example, in the case of the acceptance of the products returned after consumption). 
The implementation of the WEEE and RoHS directives proved to be difficult, and only one-third of the waste from electrical and electronic equipment was collected and properly treated [26]. Consequently, in 2012, following a long legislative process, the modification of Directive 2012/19/EU (WEEE) [27] and of Directive 2012/18/EU (RoHS) [28] was approved, but the regime based on extended producer responsibility has remained unchanged.

At the national level, still on the level of the general discipline on waste, the regulation on EPR is contained in art. 178 bis of Legislative Decree 3 April 2006, n. 152 [29] entitled "Extended responsibility of the producer" and inserted in the single environmental text by article 3 of the legislative decree 3 December 2010, n. 205 [30]. This provision does not go, in concrete, beyond a mere affirmation of principle, concretized with primary legislation and on a precise European constraint, i.e., in the implementation of specific directives, such as the directive 2012/19/EU on Waste Electrical and Electronic Equipment-WEEE.

On the contrary, in the United States, there is no unique position about the EPR. Much of the legislation on the subject derives from the courts (after all, we are in a common-law system), often contradictory in this respect, as well as with respect to the applicable legislation [31]. In any case, US companies are the most avant-garde in terms of protecting the environment for e-waste [32].

In another example of a non-European Country, Korea, the EPR related to e-waste was introduced in 2003 [33].

Therefore, to date, in terms of e-waste in the EU states, hence also in Italy, an attempt is being made to promote sustainable development, moving from a linear economy, based on the typical scheme extract, produce, usage, and disposal to a circular economy, in which it is necessary to prevent waste and promote recycling activities $[34,35]$. The circular economy is, therefore, a planned economic system to reuse materials in successive production cycles, reducing waste to the minimum [36].

Instead of being thrown away, the product should be returned to the manufacturer according to the logic of reverse logistics. In other words, the positive impacts of the circular economy are derived from the adoption of recovery, reuse, recycling, sharing, and collaboration practices. These practices make it possible to replace raw materials along the different stages of the value chain, whether they are products or services, starting from innovation in the concept and design phase, leading to the definition of recovery processes and reverse logistics typical of management of products at the end of their life-cycle.

In this scenario, the proposed work aims to identify and evaluate the possibility to enhance the e-waste hierarchy applied to RFID tags from the producer point of view, analyzing different solutions to improve the environmental impact and reduce the EPR of the producer at any level of the waste chain. In this perspective, the novelty of this work consists on analyzing and proposing solutions for the RFID e-waste hierarchy, while to date, the actual concern is only related to employing RFID tags for general waste traceability and control, without considering the impact of RFID as e-waste themselves or to the material recovery from RFIDs [37], which is only the last step of the e-waste chain. Possibilities among waste prevention, reuse, recycle, energy harvesting, and disposal are investigated to identify the best solution related to each type of RFID product, as well as cost/benefit analysis for the producer. The paper is structured as follows: The introduction provides background about RFID technology and related drawbacks about e-waste and environmental impact. Thus, the aim of this work is to propose solutions to mitigate the problem in accordance with the current legislation. In the Materials and Methods section, the adopted research approaches are reported, while in the Results and Discussion, the proposed analysis and solution are enucleated. Finally, the Conclusions recaps the conducted work.

\section{Materials and Methods}

The present work is considered to be empirical, conducted with the aim of deeply collecting information in a real-life scenario, since the boundaries between phenomena and background are not well-defined. The method can be considered quantitative once the variables are analyzed by 
measurable values. Investigative research is an initial step when understanding the subject matter does not allow definite conclusions [38].

First, an in-depth analysis of RFID tags technology was conducted in order to understand advantages, as well as drawbacks and impediments of current devices, for the e-waste hierarchy improvement. An RFID system mainly consists of two fundamental components (Figure 3): A tag (transponder image/tag) that contains, in a dedicated memory, information about the object to be identified on its location, and a reader which queries and receives information in response to the tag interrogation and can compare it with that contained in a database, to which it is connected to the network [39].

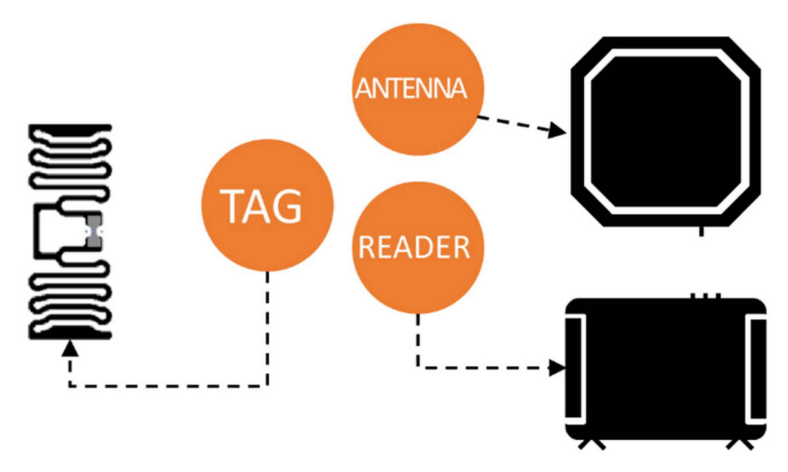

Figure 3. Typical Radio Frequency Identification (RFID) system block scheme.

The reader is represented by a transceiver, controlled by a microprocessor, and can be classified according to whether the antenna is integrated or external. To interact with contact transponders or at very short distances, it is sufficient to use very small antennas, while for operating at higher distances, larger antennas are usually required.

As for the TAGs, the classification instead takes a greater number of parameters into consideration (Figure 4): The presence or absence of a memory chip, the frequency of operation, the possibility to use TAGs for Read-Only operations or Read-Write operations, and finally, the power supply requirements, which are different for active, semi-passive or passive TAGs [40]. Low-frequency and read-only passive tags are the ones most commonly used, as they are typically low-cost, small-sized devices that allow for many types of applications $[40,41]$.

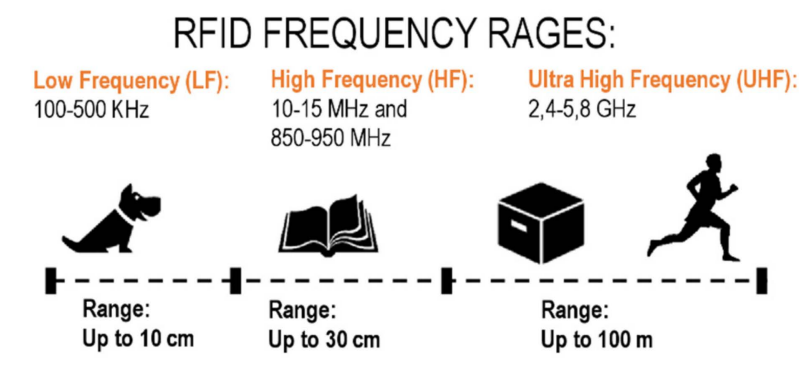

(a)

Figure 4. Cont. 


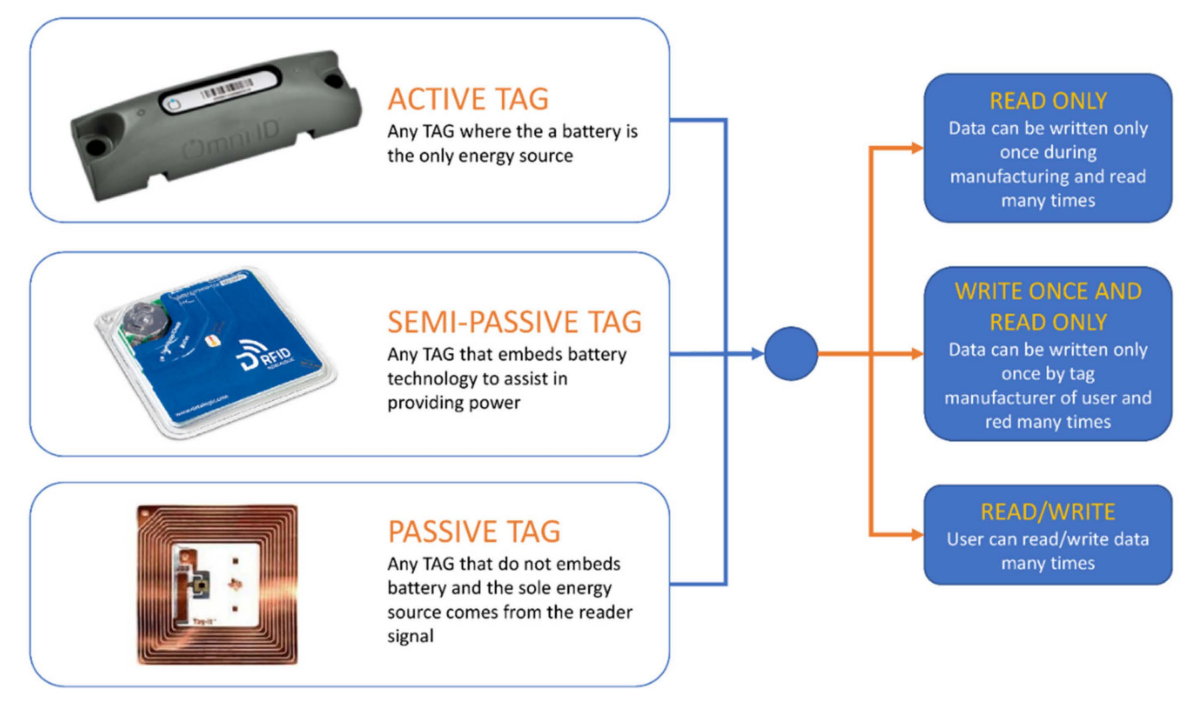

(b)

Figure 4. RFID technology classification based on (a) the frequency of operation; (b) active, semi-passive, or passive circuitry.

They are, in fact, constituted only by an antenna (typically printed) and by a miniaturized integrated circuit (IC). The height of passive TAGs can also be of a few hundred microns and can, therefore, be integrated into credit cards, adhesive labels, buttons, and other small plastic objects, sheets of paper, banknotes, and entrance tickets, thus generating real "talking" smart objects.

Once specific information was acquired about the technology and device characteristics, such as design methods and employed materials, a deep research was performed by means of desk research technique in order to investigate among all solutions and possibilities currently available in literature for each class of RFID tag and to promote reduction of e-waste production, acting at every step of the e-waste hierarchy, in accordance with Italian and, more in general, global WEEE directive and, therefore, with the EPR.

Regarding technical information about RFID technology and systems related to the analysis of potential prevention, reuse, recycle, and efficient disposal of tags, as well as cost/benefit analysis, several reliable papers and conference proceedings have been considered by means of specific research with proper keywords, as summarized in Table 1.

Table 1. List of considered papers, ordered by date, based on specific keywords.

\begin{tabular}{|c|c|c|c|c|}
\hline Date & Authors & Title & Publisher & Keywords \\
\hline 1997 & Tuttle J.R. & $\begin{array}{l}\text { Traditional and emerging technologies and } \\
\text { applications in the radio frequency } \\
\text { identification (RFID) industry. }\end{array}$ & IEEE Conference & RFID \\
\hline 2003 & Mcfarlane, D.; Sheffi, Y. & $\begin{array}{l}\text { The Impact of Automatic Identification on } \\
\text { Supply Chain Operations. }\end{array}$ & $\begin{array}{l}\text { International Journal of } \\
\text { Logistics Management }\end{array}$ & RFID and supply chain \\
\hline \multirow{2}{*}{2005} & S. Steudel, K. et al. & \multirow{2}{*}{$\begin{array}{l}50 \mathrm{MHz} \text { rectifier based on an organic diode. } \\
\text { Progress towar development of all-printed } \\
\text { RFID tags: Materials, processes, and devices. }\end{array}$} & Nature Materials & RFID \\
\hline & Subramanian V. et al. & & Proceedings of the IEEE & RFID tags \\
\hline 2006 & Suhong, Li; Visich J.K. & $\begin{array}{l}\text { Radio Frequency Identification: Supply } \\
\text { Chain Impact and } \\
\text { Implementation Challenges. }\end{array}$ & $\begin{array}{l}\text { International Journal of } \\
\text { Integrated Supply } \\
\text { Management }\end{array}$ & RFID and supply chain \\
\hline \multirow{3}{*}{2007} & Kelepouris T. et al. & $\begin{array}{l}\text { RFID-enabled traceability in the food } \\
\text { supply chain }\end{array}$ & $\begin{array}{l}\text { Industrial Management \& } \\
\text { Data Systems }\end{array}$ & RFID and supply chain \\
\hline & Lee, J. et al. & $\begin{array}{l}\text { Present status of the recycling of waste } \\
\text { electrical and electronic equipment in Korea. }\end{array}$ & $\begin{array}{l}\text { Resources, Conservation } \\
\text { and Recycling }\end{array}$ & WEEE and EPR \\
\hline & L. Yang, A. et al. & $\begin{array}{l}\text { RFID tag and RF structures on a paper } \\
\text { substrate using inkjet-printing technology }\end{array}$ & $\begin{array}{l}\text { IEEE Trans. on Microwave } \\
\text { Theory and Techniques }\end{array}$ & RFID tags \\
\hline
\end{tabular}


Table 1. Cont.

\begin{tabular}{|c|c|c|c|c|}
\hline Date & Authors & Title & Publisher & Keywords \\
\hline \multirow{3}{*}{2008} & Fosso Wamba, S. et al. & $\begin{array}{l}\text { Exploring the impact of RFID technology and } \\
\text { the EPC network on mobile B2B eCommerce: } \\
\text { A case study in the retail industry. }\end{array}$ & $\begin{array}{l}\text { International Journal of } \\
\text { Production Economics }\end{array}$ & $\begin{array}{l}\text { RFID and supply chain } \\
\text { and mobile commerce }\end{array}$ \\
\hline & Riddle, A. & $\begin{array}{l}\text { RFID for All [review of "RFID Technology } \\
\text { and Applications" by S.B. Miles, S.E. Sarma, } \\
\text { and J.R. Williams; 2008]. }\end{array}$ & IEEE Microwave Magazine & RFID \\
\hline & Thomas V.M. & Environmental Implications of RFID. & $\begin{array}{l}\text { Proc. IEEE Int'l Symp. } \\
\text { Electronics and the } \\
\text { Environment }\end{array}$ & RFID and e-waste \\
\hline 2011 & Bose, I.; Yan, S. & $\begin{array}{l}\text { The Green Potential of RFID Projects: } \\
\text { A Case-Based Analysis. }\end{array}$ & IT Professional IEEE & RFID and e-waste \\
\hline 2012 & Luppi, B. et al. & $\begin{array}{l}\text { The Rise and Fall of the Polluter-Pays } \\
\text { Principle in Developing Countries. }\end{array}$ & SSRN Electronic Journal & E-waste and EPR \\
\hline 2013 & Chen, J. et al. & $\begin{array}{l}\text { Supply chain management with lean } \\
\text { production and RFID application: } \\
\text { A case study. }\end{array}$ & $\begin{array}{l}\text { Expert Systems with } \\
\text { Applications }\end{array}$ & RFID and supply chain \\
\hline 2014 & Kim, T.; Glock, C. & $\begin{array}{l}\text { On the use of RFID in the management of } \\
\text { reusable containers in closed-loop supply } \\
\text { chains under stochastic container } \\
\text { return quantities. }\end{array}$ & Science Direct Journal & RFID and supply chain \\
\hline 2015 & Elia, V. et al. & $\begin{array}{l}\text { Designing Pay-As-You-Throw schemes in } \\
\text { municipal waste management services: } \\
\text { A holistic approach. }\end{array}$ & Waste Management Journal & Pay as you throw \\
\hline 2016 & Pantoli L. et al. & Energy harvester for remote sensors systems. & $\begin{array}{l}\text { Int. Multidisciplinary } \\
\text { Conference on Computer and } \\
\text { Energy Science (SpliTech) }\end{array}$ & $\begin{array}{l}\text { RFID tags and power } \\
\text { supply }\end{array}$ \\
\hline \multirow{4}{*}{2017} & De Oliveira Neto, G. et all & $\begin{array}{l}\text { Economic and environmental assessment of } \\
\text { recycling and reuse of electronic waste: } \\
\text { Multiple case studies in Brazil and } \\
\text { Switzerland. }\end{array}$ & $\begin{array}{l}\text { Resources, Conservation and } \\
\text { Recycling Journal }\end{array}$ & E-waste and recycling \\
\hline & Favot, M.; Grassetti, L. & $\begin{array}{l}\text { E-waste collection in Italy: Results from an } \\
\text { exploratory analysis. }\end{array}$ & Waste Management & E-waste \\
\hline & Leoni, L. et al. & $\begin{array}{l}\text { 90/900 MHz IC architecture for } \\
\text { autonomous systems. }\end{array}$ & $\begin{array}{l}\text { Int. Multidisciplinary } \\
\text { Conference on Computer and } \\
\text { Energy Science (SpliTech) }\end{array}$ & RFID and power supply \\
\hline & Safraou A. et al. & $\begin{array}{l}\text { RF Harvesting Circuit for Batteryless } \\
\text { Connected Sensor. }\end{array}$ & Eurosensors Conference & $\begin{array}{l}\text { RFID and IOT and } \\
\text { power supply }\end{array}$ \\
\hline \multirow{6}{*}{2018} & A. Leoni et al. & $\begin{array}{l}\text { A Combined 90/900 MHz IC Architecture for } \\
\text { Smart Tag Application. }\end{array}$ & $\begin{array}{l}\text { Journal of Communications } \\
\text { Software and Systems }\end{array}$ & RFID and power supply \\
\hline & Stornelli, V. et al. & $\begin{array}{l}\text { A Multi-Source Energy Harvesting Sensory } \\
\text { Glove Electronic Architecture. }\end{array}$ & $\begin{array}{l}\text { Int. Conference on Smart and } \\
\text { Sustainable Technologies } \\
\text { (SpliTech) }\end{array}$ & RFID and power supply \\
\hline & Yang, S. et al. & $\begin{array}{l}\text { Opportunities for Industry } 4.0 \text { to } \\
\text { Support Remanufacturing. } \\
\text { Decision Support Model for Evaluating }\end{array}$ & MPDI Appl. Sci. Journal & Circular economy \\
\hline & Aidonis, D. & $\begin{array}{l}\text { Alternative Waste Electrical and Electronic } \\
\text { Equipment Management Schemes }\end{array}$ & MPDI Sustainability Journal & WEEE \\
\hline & Cordova-Pizarro, D. et al. & $\begin{array}{l}\text { Circular Economy in the Electronic Products } \\
\text { Sector: Material Flow Analysis and Economic } \\
\text { Impact of Cellphone E-Waste in Mexico. }\end{array}$ & MPDI Sustainability Journal & $\begin{array}{l}\text { E-waste and Circular } \\
\text { economy }\end{array}$ \\
\hline & Isernia, R. et al. & $\begin{array}{l}\text { The Reverse Supply Chain of the E-Waste } \\
\text { Management Processes in a Circular } \\
\text { Economy Framework: Evidence from Italy. }\end{array}$ & MPDI Sustainability Journal & $\begin{array}{l}\text { E-waste and supply chain } \\
\text { and circular economy }\end{array}$ \\
\hline \multirow[t]{6}{*}{2019} & Kouhizadeh, M. et al. & $\begin{array}{l}\text { At the Nexus of Blockchain Technology, the } \\
\text { Circular Economy, and Product Deletion. }\end{array}$ & MPDI Appl. Sci. Journal & Circular economy \\
\hline & Leal Filho, W. et al. & $\begin{array}{l}\text { An overview of the problems posed by } \\
\text { plastic products and the role of extended } \\
\text { producer responsibility in Europe }\end{array}$ & Journal of Cleaner Production & Waste and ERP and EU \\
\hline & Rubio, S. et al. & $\begin{array}{l}\text { Effectiveness of extended producer } \\
\text { responsibility policies implementation: The } \\
\text { case of Portuguese and Spanish packaging } \\
\text { waste systems. }\end{array}$ & Journal of Cleaner Production & ERP and EU \\
\hline & Shevchenko, T. et al. & $\begin{array}{l}\text { Understanding Consumer E-Waste Recycling } \\
\text { Behavior: Introducing a New Economic } \\
\text { Incentive to Increase the Collection Rates. } \\
\text { Determinants of Residents' E-Waste }\end{array}$ & MPDI Sustainability Journal & E-waste and recycling \\
\hline & Thi Thu Nguyen, H. et al. & $\begin{array}{l}\text { Recycling Behavioral Intention: A Case Study } \\
\text { from Vietnam. }\end{array}$ & MPDI Sustainability Journal. & E-Waste and recycling \\
\hline & Weber, G. et al. & $\begin{array}{l}\text { Promoting Waste Degrowth and } \\
\text { Environmental Justice at a Local Level: The } \\
\text { Case of Unit-Pricing Schemes in Spain. }\end{array}$ & Ecological Economics & $\begin{array}{l}\text { Waste and political } \\
\text { ecology }\end{array}$ \\
\hline
\end{tabular}

The web was used to search for the complete texts of the laws and to identify the companies that use RFID tags. The same web highlighted the lack of companies that are concerned with the reuse and recycling of RFID tags. In fact, by typing the keywords "RFID" and "e-waste tags", the obtained results are all related to companies that use tags for the traceability of waste. Only SMART RES s.p.a. is concerned with producing biodegradable RFID tags. In Table 2, these websites are reported, sorted according to the keywords and the date of access. 
Table 2. List of companies that use RFID tags: keywords of research, websites, and date of access.

\begin{tabular}{|c|c|c|}
\hline Keywords & Link & Accessed \\
\hline Tags RFID & http://www.tagapplication.it/rfid & 28 June 2019 \\
\hline Tags and Recycling & $\begin{array}{l}\text { https://www.rand.org/pubs/technical_reports/ } \\
\text { TR1283.html. }\end{array}$ & 28 June 2019 \\
\hline Tags and E-Waste & $\begin{array}{l}\text { https://www.sistemaambientelucca.it/it/homepage/ } \\
\text { https://www.smartres.eu/tecnologia/ } \\
\text { http://www.xenoenergy.com/eng/main/default.asp }\end{array}$ & $\begin{array}{l}28 \text { June } 2019 \\
28 \text { June } 2019 \\
30 \text { June } 2019\end{array}$ \\
\hline $\begin{array}{l}\text { E-Waste and Gazzetta } \\
\text { Ufficiale (italiana) }\end{array}$ & $\begin{array}{l}\text { https://www.oecd.org/env/tools-evaluation/ } \\
\text { extendedproducerresponsibility.html } \\
\text { https://eur-lex.europa.eu/legal-content/en/ALL/ } \\
\text { ?uri=CELEX\%3A32008L0050 } \\
\text { https://eur-lex.europa.eu/legal-content/EN/TXT/ } \\
\text { ?uri=celex\%3A32012L0019 } \\
\text { https://scholarship.law.marquette.edu/cgi/ } \\
\text { viewcontent.cgi?referer=\&httpsredir=1\&article= } \\
\text { 1023\&context=mulr } \\
\text { https://www.gazzettaufficiale.it/atto/serie_generale/ } \\
\text { caricaDettaglioAtto/originario?atto. } \\
\text { dataPubblicazioneGazzetta=2006-04-14\&atto. } \\
\text { codiceRedazionale=006G0171 } \\
\text { https://www.gazzettaufficiale.it/eli/id/2010/12/10/ } \\
\text { 010G0235/sg }\end{array}$ & $\begin{array}{l}28 \text { June } 2019 \\
28 \text { June } 2019 \\
29 \text { June } 2019\end{array}$ \\
\hline $\begin{array}{l}\text { Circular Economy } \\
\text { and Definition }\end{array}$ & https://www.ellenmacarthurfoundation.org/ & 28 June 2019 \\
\hline $\begin{array}{l}\text { Resource efficiency and } \\
\text { Circular economy }\end{array}$ & $\begin{array}{l}\text { http://www.europarl.europa.eu/factsheets/it/sheet/ } \\
\text { 76/efficienza-delle-risorse-ed-economia-circolare }\end{array}$ & 28 June 2019 \\
\hline
\end{tabular}

\section{Results and Discussion}

In this section, results of the conducted research about the problem of e-waste in general and to the RFID tags in particular for the producer are proposed, following the solutions based on the hierarchical principle of waste to avoid the EPR. For this purpose, the section has been organized in subparagraphs, as follows:

1. Prevention in the production of waste;

2. Reuse;

3. Recycling;

4. Disposal.

\subsection{Prevention}

According to the waste hierarchy principle, priority should be given to the prevention in the production of waste itself. The first and most important action to block the issue of waste is not to produce waste. However, it was largely demonstrated how RFID technology enables great advantages and enhancements for the environment and the production. Thus, not producing such devices could generate more disadvantages than benefits. Therefore, form the prevention point of view, it is necessary to operate at the design stage in order to obtain an eco-sustainable product where parts and materials can be easily disassembled.

As we mentioned before, tags can be active, passive, or semi-passive. The possibility of an eco-sustainable design depends on whether the tag is active and semi-passive or passive.

The passive tags have no internal power source, but draw energy from the radio waves sent by the reader that queries them to activate and retransmit the data, while the active tags, like the semi-passive 
ones, are powered by a battery which lasts for almost 3-5 years. However, once the battery runs out, the tag (or at least the battery) must be replaced.

The $125 \mathrm{kHz}$ and $13.56 \mathrm{MHz}$ tags, according to the ISO standards, are passive (without batteries), while for the UHF RFID technology, active, semi-passive, and passive TAGs can be employed.

The active tags are powered by batteries. The semi-passive tags are powered by batteries only to keep the internal circuit part active, while for signal irradiation, they use a part of the energy received from the radio wave that also transmits the information.

However, when the battery is present, it is not deeply integrated into the RFID system and can be removed. Since it is not possible to conceive an eco-sustainable design for the battery, the latter should be selected to have the highest energy capability per volume in order to extend the battery lasting. On the other hand, such a solution has some drawbacks related to costs and environmental impact for each battery technology. Therefore, a proper compromise should be considered while choosing the battery technology for the RFID device. In order to achieve the aforementioned target, the Lithium Thionyl Chloride technology for batteries is often used, since it offers promising performance in terms of energy density and costs (Table 3).

Table 3. Classification of battery technologies mostly used for RFID devices.

\begin{tabular}{|c|c|c|c|c|c|}
\hline$"$ & Rechargeable & $\begin{array}{l}\text { Energy } \\
\text { Density } \\
{[\mathrm{Wh} / \mathrm{L}]}\end{array}$ & Cost $[W h / \$]$ & $\begin{array}{l}\text { Disposal } \\
\text { Classification }\end{array}$ & Proper Disposal \\
\hline Alkaline & No & $250-434$ & 0.47 & Non-Hazardous & $\begin{array}{l}\text { Trash (normal } \\
\text { municipal waste) }\end{array}$ \\
\hline Carbon Zinc & No & 92 & 3.02 & Non-Hazardous & $\begin{array}{l}\text { Trash (normal } \\
\text { municipal waste) }\end{array}$ \\
\hline Lithium, Li-Ion & Yes & 560 & 2.68 & Hazardous & Recycle \\
\hline Nickel-cadmium & Yes & 100 & 3.22 & Hazardous & $\begin{array}{c}\text { Recycle or Household } \\
\text { Hazardous Waste } \\
\text { Collection Site }\end{array}$ \\
\hline $\begin{array}{l}\text { Nickel Metal } \\
\text { Hydride }\end{array}$ & Yes & 401 & 3.22 & $\begin{array}{l}\text { Non-hazardous } \\
\text { waste }\end{array}$ & $\begin{array}{l}\text { Recycle or place in the } \\
\text { trash (normal } \\
\text { municipal waste) }\end{array}$ \\
\hline Mercury Oxide & No & $300-500$ & & Hazardous & $\begin{array}{c}\text { Household Hazardous } \\
\text { Waste Collection Site }\end{array}$ \\
\hline $\begin{array}{l}\text { Lithium Thionyl } \\
\text { Chloride }\end{array}$ & No & 1200 & 5.1 & Hazardous & Recycle \\
\hline
\end{tabular}

The Lithium Thionyl Chloride offers the highest energy density compared to other chemistries, with an average lasting up to 10 years for low-power applications. These batteries are able to sustain extremely low temperatures, enabling their employment for many outdoor applications, and they also produce limited emissions under abusive conditions, which is an advantage over other battery chemistries that use liquid to produce a gas byproduct.

In order to overcome the battery disposal problem from an eco-sustainable design point of view, an alternative can be found in novel, battery-less RFID technologies that rely on RF energy harvesting techniques $[42,43]$ to gather the required energy for the tag from the environment or directly from an additional reader signal [44]. This solution comprehends the usage of few active devices, such as diodes, passive electronic components, and ICs, which are much less hazardous compared to batteries and allow for a theoretical endless usage.

Besides the power supply aspect, which involves only active and semi-passive tags, the crucial aspect for a sustainable design that allows waste and environmental impact prevention is the material choice involved for tag production. Nowadays, research and development (R\&D) and industrial production include an extensive variety of electrical components that can be produced and directly included in low-cost manufacturing processes that mostly involve organic electronic components, conductive and semi-conductive materials-also known as green materials-being considered as a 
promising technology for an environmentally friendly, low-cost alternative for standard production processes. The usage of organic materials allows simple production techniques that do not require particular equipment, clean rooms, or hazardous chemistry. On the contrary, it is possible to implement passive electronic or electromagnetic structures with low-cost procedures, such as inkjet printing, which is suitable for passive tags implementation [45]. To date, researchers have demonstrated the possibility to exploit such organic technology for active electronic component implementation, like diodes and ICs, that enables the possibility for future implementation of a fully organic, zero environmental impact RFID tag [46-48].

In Italy, the idea of such a green tag, as mentioned in the introduction section, was already implemented by Smartres s.p.a. Company, which has implemented some low environmental impact tags. In 2005, Smartres patented a proprietary RFID manufacturing technology called inlay-less, mainly based on the usage of additive copper manufacturing that does not require any chemical process for conductive structures implementation. The Smartres technology employs copper microwires that can be used for conductive traces implementation that are thermally transferable over a large variety of materials without the need of the intermediate plastic substrate (Figure 5). Without the usage of inlays, it is possible to implement RFID tags over biodegradable labels or supports, such as polyamide, paper, and textile, that are ecofriendly and can be easily disposed of without environmental threats [49].

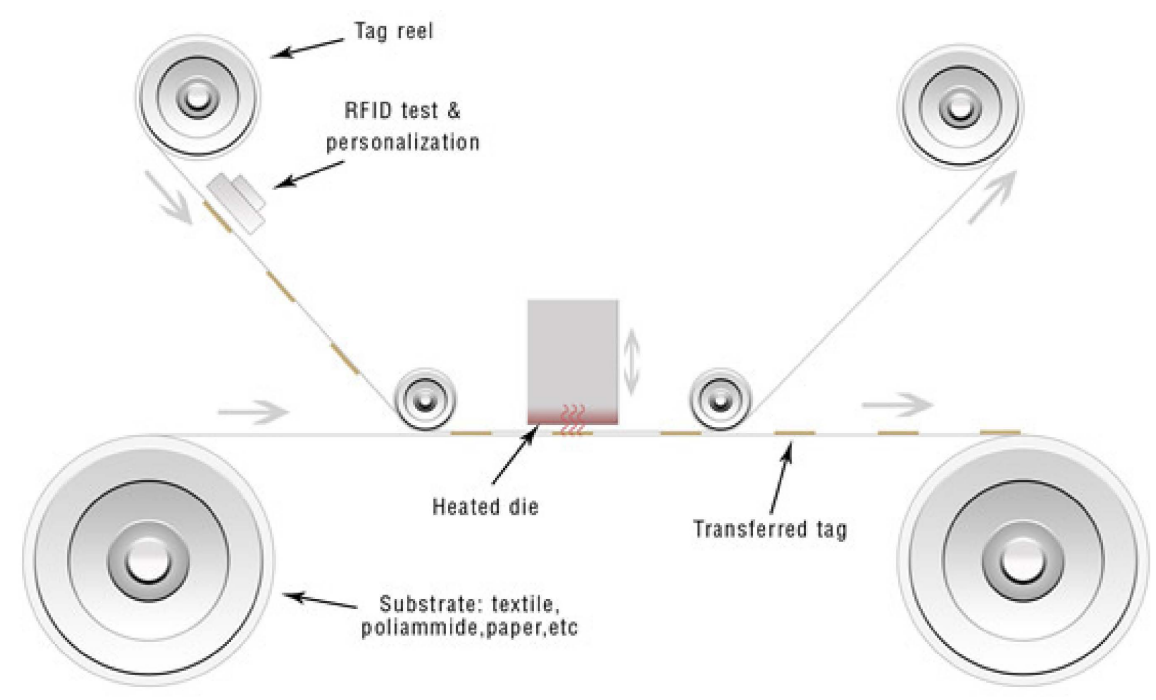

Figure 5. The Smartres s.p.a. inlay-less RFID technology.

\subsection{Reuse}

In this section, opportunities, advantages, and disadvantages of RFID tags reuse are discussed based on recent technology and standards that involve tags manufacturing and protocols.

The key aspects that allow an RFID tag to be reusable during its lifetime are the possibility to be rewritable many times and its robustness, i.e., the capability to keep its electrical and mechanical integrity over time.

According to the Electronic Product Code (EPC) and ISO18000 standards, as depicted in Table 4, not all the tags can be rewritten since they are manufactured to be programmed only once and are intended for Read-Only purposes. 
Table 4. RFiD EPC classification.

\begin{tabular}{|c|c|c|c|c|}
\hline EPC Class & Standard & Frequency & Power Supply & Memory \\
\hline Class 0 Gen 1 & $\begin{array}{c}900 \mathrm{MHz} \text { Class 0-RF } \\
\text { Identification-Tag Specification }\end{array}$ & UHF & Passive & Read-Only \\
\hline \multirow[t]{5}{*}{ Class 1 Gen 1} & $\begin{array}{c}\text { 13.56 MHz ISM Band Class } 1 \\
\text { RF Identification } \\
\text { Tag Interface Specification }\end{array}$ & HF-UHF & Passive & $\begin{array}{l}\text { WORM } \\
\text { (Write once, } \\
\text { read many) }\end{array}$ \\
\hline & 860 MHz-930 MHz Class 1 & & & \\
\hline & RF Identification & & & \\
\hline & Tag RF andLogical Communication & & & \\
\hline & Iterface Specification & & & \\
\hline & $\begin{array}{l}\text { EPCglobal Tag Data Standards } \\
\text { Version } 1.3\end{array}$ & & & \multirow{6}{*}{$\begin{array}{l}\text { WORM } \\
\text { (Write once, } \\
\text { read many) }\end{array}$} \\
\hline \multirow{5}{*}{ Class 1 Gen 2} & Class 1 Gen2 UHF Air Interface & \multirow{5}{*}{ UHF } & \multirow{5}{*}{ Passive } & \\
\hline & Protocol Standard Version 1.0.9 & & & \\
\hline & Class 1 Gen 2 UHF RFID & & & \\
\hline & Conformance Requirements & & & \\
\hline & Specification v.1.0.2 & & & \\
\hline Class 2 & $\begin{array}{c}\text { EPCglobal } \\
\text { Hardware Action Group (HAG) }\end{array}$ & UHF & $\begin{array}{c}\text { Passive } \\
\text { Semi-Passive } \\
\text { Active }\end{array}$ & Rewritable \\
\hline
\end{tabular}

With regard to active and semi-passive tags, they are always rewritable and thus reusable. Usually, the package is made of rigid plastic or flexible protective material, allowing the device to be resistant to its usage over time. The only concern is the battery, which is a limited energy source and limits the lifetime of the tag. Solutions to this problem, referring to general purpose applications, consist of battery replacement or the employment of rechargeable batteries.

As shown in Table 5, which refers to coin-size battery comparison with a capacity ranging from $40 \mathrm{mAh}$ to $50 \mathrm{mAh}$, and without loss of generality, the employment of rechargeable batteries represents a higher initial investment with respect to non-rechargeable battery endowment. However, they can be recharged and, consequently, reused up to 2000 times, allowing the producer to ideally save over time around $\$ 500$ in the worst case and around $\$ 5100$ in the best case per each employed rechargeable battery.

Table 5. Comparison rechargeable/non-rechargeable coin-size batteries.

\begin{tabular}{|c|c|c|c|c|}
\hline Type & Capacity & Chemistry & $\begin{array}{l}\text { Costs }{ }^{1} \\
\text { [\$/unit] }\end{array}$ & Cycle Durability \\
\hline Non-rechargeable & $40-50 \mathrm{mAh}$ & $\begin{array}{c}\text { Alkaline Manganese Dioxide } \\
\text { Lithium } \\
\text { Lithium Manganese Dioxide } \\
\text { Lithium Poly-Carbon } \\
\text { Monofluoride } \\
\text { Silver Oxide }\end{array}$ & $0.43-2.55$ & 1 \\
\hline Rechargeable & $45 / 50 \mathrm{mAh}$ & $\begin{array}{l}\text { Lithium Manganese } \\
\text { Nickel Metal Hydride }\end{array}$ & $2.52-9.49$ & $1200-2000$ \\
\hline
\end{tabular}

Active RFID tags are usually used for tracking high-value resources over a large zone. They could be used for tracking vehicles in a lot or for tracking valuable objects or equipment within a structure. They are most beneficial when items need to be firmly controlled. Consequently, the number of active tags usually employed is relatively small, compared to general-purpose passive tags that are used, e.g., in warehouses and distributions, retails and point-of-sale, inventory management, and supply chains.

Therefore, reuse possibilities for passive RFID tags represent a valuable and relevant aspect within the EEE waste hierarchy in terms of economic and environmental impact. As mentioned for active tags, one of the crucial properties that an RFID device should have to enable the opportunity of reuse is the possibility to rewrite information. However, referring to Table 2, the majority of HF-UHF passive tags are intended to be Read-Only or WORM devices, invalidating any reuse chances, since there is no possibility to store new information into the recovered device memory. However, the new, second-generation of EPC Class 1 UHF passive tags, which is one of the most used in RFID systems, 
actually widens the opportunities of usage. Indeed, the protocol states that the internal memory can be read or written, with two distinct commands: Write command, which stores a single 16-bit word, and BlockWrite command, which allows writing one or more 16-bit words per time. The standard also includes two levels or password, kill password and access password, that allows to lock or permanently lock write operations, or to enable or permanently enable such command with or without encryption. Consequently, this protocol allows reusing the tag since it can be rewritten without privacy or counterfeit problems, and since the write operation can be enabled and password protected. On the other hand, setting up a write password will have an impact on the tag production process, since the write operation can require more time when it is password protected. Therefore, production will be affected by higher production costs. In Figure 6, code differences between writing and write with lock operation are illustrated for the Bixolon SLP-TX400 RFID tag label printer, showing that the secured writing operation requires two additional instructions.

\begin{tabular}{|c|c|}
\hline & COMMANDS \\
\hline EPC SIMPLE & T56, 32, 4, 1, 1, 0, 0, N, B, 'RFID Print Test 1' \\
\hline \multirow[t]{4}{*}{ DATA WRITING } & T57, 81, 2, 1, 1, 0, 0, N, N, 'RFID Data: 0101010101010101010101 01' \\
\hline & $>$ RFW, E, ' $1,1,1,1,1,1,1,1,1,1,1,1$ ' $\rightarrow$ EPC Data Writing \\
\hline & $\mathrm{T} 59,351,4,1,1,0,0, \mathrm{~N}, \mathrm{~B}$, '*Complete*' \\
\hline & P1 \\
\hline EPC SECURED & $>$ RFZ, '00000000, 00000000, 33333333, 33333333' $\rightarrow$ Access/Kill Password Modification \\
\hline WRITING & T56, 32, 4, 1, 1, 0, 0, N, B, 'RFID Write and Lock Test' \\
\hline \multirow[t]{5}{*}{ (WRITE \& LOCK) } & T57, 81, 2, 1, 1, 0, 0, N, N, 'RFID Data: 0101010101010101010101 01' \\
\hline & $>$ RFW, E, ' $1,1,1,1,1,1,1,1,1,1,1,1$ ' $\rightarrow$ EPC Data Writing \\
\hline & $>$ RFLK $\rightarrow$ Regular Locking of Kill, Access, and EPC Data \\
\hline & $\mathrm{T} 59,351,4,1,1,0,0, \mathrm{~N}, \mathrm{~B},{ }^{\prime *}$ Complete*' \\
\hline & P1 \\
\hline
\end{tabular}

Figure 6. The Bixolon SLP-TX400 RFID code examples for writing and secured writing operations.

The second important feature for reuse of passive RFID tags is the durability. Most UHF passive tags are manufactured over plastic or paper self-adhesive labels. Thus, the process of removing the tag from an object could destroy the link between the RFID chip and the antenna, compromising the functionality of the tag itself. In other words, UHF passive tags cannot be easily reused, unless they are enclosed in protective plastic or other material that will allow them to survive the removal process.

In Table 4, several UHF passive tags with different substrate materials and relative costs are reported. It is evident that the price of a simple, self-adhesive paper tag is lower, but the difference is not as significant, especially when some additional features are required for a normal cycle of operation, such as waterproof features for outdoor applications, which typically occur in the supply chain.

Based on all the variables that have been identified for the reuse process of UHF passive RFID tags, it is possible to project a cost/benefit hypothetical analysis, with the following considerations:

- The time needed for different tag writing operations may differ, depending on technology and data payload to be programmed. For this analysis, the example codes of Figure 7 have been considered, with five commands and seven commands for a simple write operation and secured writing operation, respectively, and assigning a uniform computational cost per each operation.

- Prices associated with each type of passive tag may vary, depending on the producer and requested quantity. Best case, lower costs for standard, self-adhesive tags and pet flexible, transparent tags-as reported in Table 6-have been considered.

- Not all the tag programmers are compatible with password read/write operations. However, the initial investment for a proper programmer has not been considered, since it is strongly dependent on many other factors that are linked to the needs of the company. 
Table 6. Comparison of UHF RFID passive tags with different material substrates.

\begin{tabular}{cccc}
\hline Substrate Type & Technology & Size & Cost $^{\mathbf{1}}$ [\$/Unit] \\
\hline Self-adhesive paper & Alien H3 & $100 \times 25 \mathrm{~mm}$ & $0.05-0.06$ \\
Pet flexible, transparent & Alien H3 & $73 \times 23 \mathrm{~mm}$ & $0.09-0.12$ \\
Waterproof self-adhesive & Alien H3/H4 & $100 \times 25 \mathrm{~mm}$ & $0.10-0.15$ \\
Textile washable & Alien H3 & $85 \times 27 \mathrm{~mm}$ & $0.02-0.15$ \\
PET flexible, anti-metal & Monza MR6-P & $40 \times 25 \mathrm{~mm}$ & $0.25-0.45$ \\
Flexible silicone & Alien H3 & $55 \times 12 \times 2.5 \mathrm{~mm}$ & $0.35-0.7$ \\
\hline
\end{tabular}

${ }^{1}$ Prices vary according to requested tag quantity.

The increase of time required for a single secured write operation, for reuse purposes, can be computed as the ratio between the number of instructions A needed for password write and the number of instructions B required for a simple write operation, which is equal to 1:4. This limits the maximum number of tags that can be written over time. If a company produces 1000 standard tags per day, the maximum rewritable tag number, for the same company, will be 714 . Based on this consideration, an annual cost prospect is followed (Figure 7), with different percentages of returned tags. It can be noticed that, in this configuration, the annual costs for a company that adopts the reuse process is lower as the returned tags are more than $30 \%$ of the total amount of tags. Moreover, the annual amount of programmed tags corresponds to $365 \mathrm{~K}$ for a standard process and to $260 \mathrm{~K}$ for a reuse-enabled process, since the maximum number of programmable tags per day is reduced. If each tag is sold at a price three times greater than the self-adhesive paper tag purchase price, for both standard and reuse processes, the cost-to-earnings ratio is increased up to $112.3 \%$ for a $50 \%$ of returned tags and up to $140.7 \%$ for a $60 \%$ of returned tags.

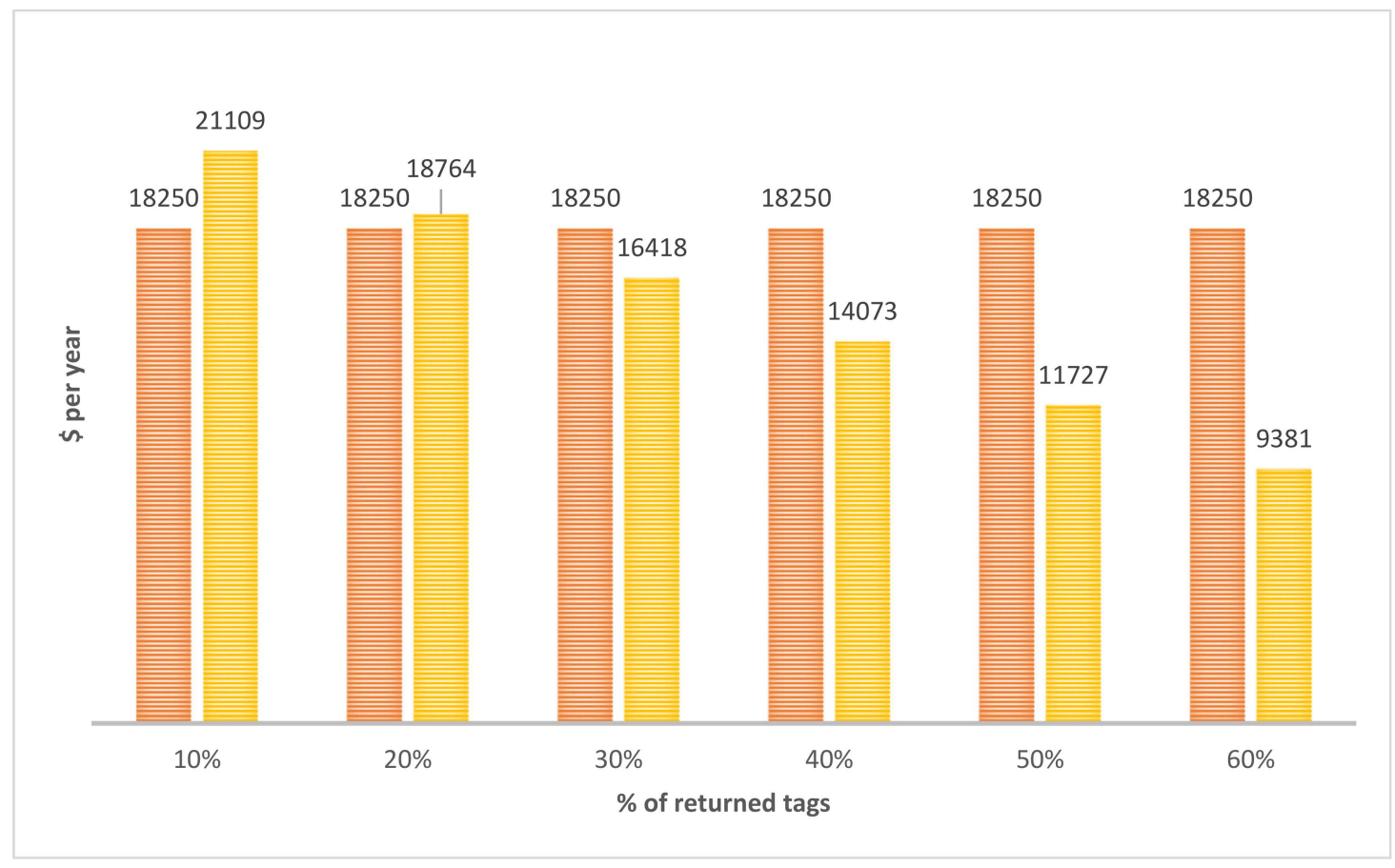

Figure 7. Annual cost projections for standard, non-reusable tags versus reused tag with different percentages. The blue bars represent the standard tags while the orange bars indicate the reuse tag process.

It is important to underline that this analysis does not take into account two important factors, which have not quantified at this stage: The first is represented by the benefit that the producer could earn with a "green image" of the company, which is associated with the reuse process. The second is 
linked to the EPR, since the total amount of e-waste that derives for RFID tags is significantly reduced, therefore the cost associated with the producer responsibility of waste production is potentially lowered.

\subsection{Recycle}

Recycling means turning waste into reusable materials. It is an effective system for reducing energy consumption in industries and for saving on raw materials.

One of the crucial points of recycling is the consumers' behavior. If the customer does not send back the product, now considered as e-waste, there is no possibility to have an efficient recycling system. Therefore, the citizens' education in the matter of e-waste treatment is essential $[50,51]$.

Moreover, the consumer, in this sense, represents an important piece for the circular economy, in order to increase the number of raw, recovered materials [50-55].

Table 7 is related to the materials that compose an RFID TAG, highlighting which of these materials, according to the Institut für Aufbereitung und Recycling RWTH Aachen University (I.A.R.) et all [38], are actually recyclable with an economic return for the producer who is concerned with recovering them.

Table 7. The theoretical environmental and economic impact of RFID tag recovered materials.

\begin{tabular}{ccccc}
\hline Component & Material & $\begin{array}{c}\text { Carbon Footprind } \\
\text { (Values Rounded) }\end{array}$ & $\begin{array}{c}\text { Market Value } \\
\text { (Ideal) }\end{array}$ & $\begin{array}{c}\text { Market Value } \\
\text { (Feasible) }\end{array}$ \\
\hline Face material & PP & $3.50 \mathrm{kgCo}_{2} / \mathrm{kg}$ & $1.4 € / \mathrm{kg}$ & $1.4 € / \mathrm{kg}$ \\
& Paper & $1.35 \mathrm{kgCo}_{2} / \mathrm{kg}$ & $0.445 € / \mathrm{kg}$ & $0 € / \mathrm{kg}$ \\
Adhesive & Acrylate & $3.34 \mathrm{kgCO}_{2} / \mathrm{kg}$ & $2.5 € / \mathrm{kg}$ & $0 € / \mathrm{kg}$ \\
$I C$ & Silicon & $85.41 \mathrm{kgCO}_{2} / \mathrm{kg}$ & $250 € / \mathrm{kg}$ & $0 € / \mathrm{kg}$ \\
IC bumps & Gold & $18,722.00 \mathrm{kgCO}_{2} / \mathrm{kg}$ & $41,540 € / \mathrm{kg}$ & $41,540 € / \mathrm{kg}$ \\
ACP & Epoxy-based material & $3.34 \mathrm{kgCO}_{2} / \mathrm{kg}$ & $2.5 € / \mathrm{kg}$ & $2.5 € / \mathrm{kg}$ \\
ACP Metal & Nickel & $5.94 \mathrm{kgCO}_{2} / \mathrm{kg}$ & $13.817 € / \mathrm{kg}$ & $24.8 € / \mathrm{kg}$ \\
Adhesive & Polyurethane & $3.34 \mathrm{kgCO}_{2} / \mathrm{kg}$ & $0.99 € / \mathrm{kg}$ & $0.99 € / \mathrm{kg}$ \\
& Copper & $3.97 \mathrm{kgCO}_{2} / \mathrm{kg}$ & $5.618 € / \mathrm{kg}$ & $8.935 € / \mathrm{kg}$ \\
Aerial & Aluminium & $14.90 \mathrm{kgCO}_{2} / \mathrm{kg}$ & $1.533 € / \mathrm{kg}$ & $2.693 € / \mathrm{kg}$ \\
& Silver (in print) & $155.48 \mathrm{kgCO}_{2} / \mathrm{kg}$ & $849 € / \mathrm{kg}$ & $849 € / \mathrm{kg}$ \\
Substrate & Bonding agent (in print & $3.34 \mathrm{kgCO}_{2} / \mathrm{kg}$ & $2.5 € / \mathrm{kg}$ & $2.5 € / \mathrm{kg}$ \\
Adhesive & PET & $3.18 \mathrm{kgCO}_{2} / \mathrm{kg}$ & $0.86 € / \mathrm{kg}$ & $0.86 € / \mathrm{kg}$ \\
\hline
\end{tabular}

\subsection{Disposal}

If the product reaches its end-of-life and none of the alternatives foreseen by the waste hierarchy are feasible, the EPR can become a problem for small- and medium-sized enterprises. Waste disposal is a cost that falls entirely on the manufacturer. Therefore, consortia have been established, generally voluntary and non-profit. In this way, free competition is guaranteed (guaranteed by Articles 101 and 102 of the Treaty on the Functioning of the European Union), since the producer is allowed to divide the disposal costs with the other producers.

These consortia are widespread internationally and are distinguished by the type of equipment or type of market served: From refrigerators to lamps and from computer equipment to small appliances.

These collective systems can have direct proprietary treatment facilities, where WEEE belonging to its members can be channelled or operated as simple "waste brokers" using third-party facilities. Nevertheless, the continuous and growing worldwide development of electric and electronic devices is linked to an increased number of e-waste. Consequently, e-waste collection and disposal management are becoming critical. Therefore, novel e-waste management models are needed and researchers are paying great attention to such problem [56].

An example, limited to Italy among the main operational collective systems, is the APIRAEE consortium, established in September 2007. Additional examples include the CCR Consortium, which is actually active in many states of the European Community, and in the United States, the Remedia Consortium. 
After all, disposing of electronic waste is a cost. It is precisely for this reason that eco-mafias are enriched with the illegal disposal of this type of waste from the electronics industry: According to UNEP data, the United Nations environmental program, $90 \%$ of the world's electronic waste is disposed of and illegally downloaded for a turnover of 19 billion dollars.

Smartphones and computers are among the objects that contribute most to accumulation. The export of hazardous and environmentally hazardous waste from OECD countries to those that are not part of it is prohibited, but thousands of tons of waste continue to be exported after being declared as secondhand goods.

Ghana, Nigeria, China, Pakistan, India, and Vietnam are turning into waste disposal centers for the illegal disposal of electronic waste, and it is believed that this also applies to very small electronic waste, including RFID TAGs $[57,58]$.

\section{Conclusions}

The present research starts with a study of e-waste in general, identifying RFID tags as the best tool for a correct management of such waste. However, the RFID tags, in turn, constitute e-waste themselves and the cost of their pollution falls, according to the legislation currently in force in Europe, on the producer, to whom the European Union itself entrusts the task of scaling the hierarchy of waste. The costs for the producer for each step of the waste hierarchy have been identified, as well as opportunities to enhance the e-waste hierarchy. In the first step, some manufacturing companies have been identified that propose an eco-design to prevent rejection. By preventing waste, obviously, the cost for the producer would be lower, because there are no concerns about the amount of e-waste. In the reuse, a possibility has been proposed to increase and improve the salvage of tags, depending on the type of tag itself, specifying which are the opportunities to be able to re-issue RFID tags on the market, based on the functionalities of the distribution. A cost/benefit analysis with a focus on passive tags, which are the most widely used ones within the industry and in the distribution supply chain sector, is also presented here. The third thread on the hierarchical scale is recycling, where we briefly focused on what are the opportunities for recovery of raw materials starting from the e-waste connected to the RFID tags, showing those that can be the real revenues or benefits that are can get from the recovery of the same materials. Finally, the last step on the waste scale is disposal, the costs of which are redistributed, through consortia, among several producers in a logic of free competition.

Author Contributions: F.C. conceived and designed the paper, structure and organization. F.C. and A.C. wrote the paper with the support of D.S. who also supported the legislative research and analyses. A.C. realizes the formal analysis under super vision of F.C. All participants coauthored the paper.

Funding: This research received no external funding.

Conflicts of Interest: The authors declare no conflict of interest.

\section{References}

1. Mcfarlane, D.; Sheffi, Y. The Impact of Automatic Identification on Supply Chain Operations. Int. J. Logist. Manag. 2003, 14, 1-17. [CrossRef]

2. Steinhilper, R.; Freiberger, S.; Kübler, F.; Böhner, J. RFID Integrated Adaption of Manufacturing Execution Systems for Energy Efficient Production. In Re-Engineering Manufacturing for Sustainability; Chapter 20; Springer: Singapore, 2013; pp. 123-128.

3. Li, S.; Visich, J.K. Radio Frequency Identification: Supply Chain Impact and Implementation Challenges. Int. J. Integr. Supply Manag. 2006, 2, 407-424. [CrossRef]

4. Kelepouris, T.; Pramatari, K.; Doukidis, G. RFID-enabled traceability in the food supply chain. Ind. Manag. Data Syst. 2007, 107, 183-200. [CrossRef]

5. Chen, J.; Cheng, C.; Huang, P. Supply chain management with lean production and RFID application: A case study. Expert Syst. Appl. 2013, 40, 3389-3397. [CrossRef] 
6. Fosso Wamba, S.; Lefebvre, L.; Bendavid, Y.; Lefebvre, É. Exploring the impact of RFID technology and the EPC network on mobile B2B eCommerce: A case study in the retail industry. Int. J. Prod. Econ. 2008, 112, 614-629. [CrossRef]

7. Sferrazza, A. Innovativi Dispositivi Tecnologici per una Maggiore Informazione nel Settore Agroalimentare: Uno Studio al Salone del Gusto. Master's Thesis, Facoltà Di Economia, Corso di Laurea in Economia e Direzione Delle Imprese, Università Degli Studi Di Torino, Torino, Italy, 2010; pp. 100-110.

8. Talone, P.; Russo, G. Rfid: Tecnologia e Applicazioni. Fondamenti delle Tecniche e Cenni Sulle Applicazioni di una Tecnologia Silenziosamente Pervasiva; Fondazione Ugo Bordoni: Roma, Italy, 2008.

9. Kim, T.; Glock, C. On the use of RFID in the management of reusable containers in closed-loop supply chains under stochastic container return quantities. Transp. Res. Part E Logist. Transp. Rev. 2014, 64, 12-27. [CrossRef]

10. Leoni, A.; Cucchiella, F.; Mastrodicasa, L.; Stornelli, V. A 3D Printable Apparatus for the Industrial Programming of NFC/RFID TAGs. In Proceedings of the 4th International Conference on Smart and Sustainable Technologies (SpliTech), Split, Croatia; 2019; pp. 1-5. [CrossRef]

11. Weber, G.; Cabras, I.; Calaf-Forn, M.; Puig-Ventosa, I.; D'Alisa, G. Promoting Waste Degrowth and Environmental Justice at a Local Level: The Case of Unit-Pricing Schemes in Spain. Ecol. Econ. 2019, 156, 306-317. [CrossRef]

12. Favot, M.; Grassetti, L. E-waste collection in Italy: Results from an exploratory analysis. Waste Manag. 2017, 67, 222-231. [CrossRef]

13. Uricchio, V. Le Nuove Frontiere della Tecnologia per la Tracciabilità dei Rifiuti e il Controllo dei Traffici Illeciti alla luce delle Innovazioni Normative Europee, 1st ed.; Cacucci: Bari, Italy, 2009; pp. 145-180.

14. Bilitewski, B. Pay-as-you-throw-A tool for urban waste management. Waste Manag. 2008, $28,2759$. [CrossRef]

15. Elia, V.; Gnoni, M.; Tornese, F. Designing Pay-As-You-Throw schemes in municipal waste management services: A holistic approach. Waste Manag. 2015, 44, 188-195. [CrossRef]

16. Awasthi, A.K.; Cucchiella, F.; D'Adamo, I.; Li, J.; Rosa, P.; Terzi, S.; Wei, G.; Zeng, X. Modelling the Correlations of E-Waste Quantity with Economic Increase. In Science of The Total Environment; Elsevier: Amsterdam, The Netherlands; Volume 613-614, pp. 46-53. [CrossRef]

17. Thomas, V.M. Environmental Implications of RFID. In Proceedings of the 2008 IEEE International Symposium on Electronics and the Environment, San Francisco, CA, USA, 19-22 May 2008; pp. 1-5. [CrossRef]

18. Cucchiella, F.; D'Adamo, I.; Rosa, P.; Terzi, S. Automotive printed circuit boards recycling: An economic analysis. J. Clean. Prod. 2016, 121, 130-141. [CrossRef]

19. Bose, I.; Yan, S. The Green Potential of RFID Projects: A Case-Based Analysis. IT Prof. 2011, 13, 41-47. [CrossRef]

20. Schindler, S.; Rebecca, H.; Schmalbein, N.; Steltenkamp, V.; Cave, J.; Wens, B.; Anhalt, A. SMART TRASH: Study on RFID Tags and the Recycling Industry; European Commission. 2012. Available online: https://www.rand.org/pubs/technical_reports/TR1283.html (accessed on 28 June 2019).

21. Global E-Waste Volume Hits New Peak in 2014: UNU Report-United Nations University. Available online: http://unu.edu/news/news/ewaste-2014-unu-report.html (accessed on 9 August 2019).

22. Leal Filho, W.; Saari, U.; Fedoruk, M.; Iital, A.; Moora, H.; Klöga, M.; Voronova, V. An overview of the problems posed by plastic products and the role of extended producer responsibility in Europe. J. Clean. Prod. 2019, 214, 550-558. [CrossRef]

23. Extended Producer Responsibility-OECD. Available online: https://www.oecd.org/env/tools-evaluation/ extendedproducerresponsibility.htm (accessed on 28 June 2019).

24. Luppi, B.; Parisi, F.; Rajagopalan, S. The Rise and Fall of the Polluter-Pays Principle in Developing Countries. SSRN Electron. J. 2012, 32, 135-144.

25. EUR-Lex-32008L0050-EN-EUR-Lex. Available online: https://eur-lex.europa.eu/legal-content/en/ALL/?uri= CELEX\%3A32008L0050 (accessed on 28 June 2019).

26. Efficienza delle Risorse ed Economia Circolare | Note Tematiche Sull’Unione Europea | Parlamento Europeo. Available online: http://www.europarl.europa.eu/factsheets/it/sheet/76/efficienza-delle-risorse-ed-economiacircolare (accessed on 28 June 2019).

27. EUR-Lex-32012L0019-EN-EUR-Lex. Available online: https://eur-lex.europa.eu/legal-content/EN/TXT/?uri= celex\%3A32012L0019 (accessed on 29 June 2019). 
28. EUR-Lex-32012L0018-EN-EUR-Lex. Available online: https://eur-lex.europa.eu/legal-content/EN/TXT/?uri= CELEX\%3A32012L0018 (accessed on 29 June 2019).

29. Gazzetta Ufficiale. Available online: https://www.gazzettaufficiale.it/atto/serie_generale/caricaDettaglioAtto/ originario?atto.dataPubblicazioneGazzetta=2006-04-14\&atto.codiceRedazionale=006G0171 (accessed on 28 June 2019).

30. Gazzetta Ufficiale. Available online: https://www.gazzettaufficiale.it/eli/id/2010/12/10/010G0235/sg (accessed on 28 June 2019).

31. Sesta, M. Sicurezza dei Prodotti Alimentari e la Responsabilità Civile nell’Unione Europea e negli Stati Uniti: Tecniche a Confronto. Ph.D. Thesis, Università di Bologna, Bologna, Italy, 2013.

32. Bergner, D.M. The Electronic Waste Recycling Act of 2003: California's Response to the Electronic Waste Crisis. Marq. L. Rev. 2004, 88, 377-389.

33. Lee, J.; Song, H.; Yoo, J. Present status of the recycling of waste electrical and electronic equipment in Korea. Resour. Conserv. Recycl. 2007, 50, 380-397. [CrossRef]

34. Rubio, S.; Ramos, T.; Leitão, M.; Barbosa-Povoa, A. Effectiveness of extended producer responsibility policies implementation: The case of Portuguese and Spanish packaging waste systems. J. Clean. Prod. 2019, 210, 217-230. [CrossRef]

35. Circular Economy-UK, USA, Europe, Asia \& South America-The Ellen MacArthur Foundation. Available online: https://www.ellenmacarthurfoundation.org/ (accessed on 28 June 2019).

36. Cucchiella, F.I.; D’Adamo, S.C.; Koh, L.; Rosa, P. A Profitability Assessment of European Recycling Processes Treating Printed Circuit Boards from Waste Electrical and Electronic Equipments. Rev. Renew. Sustain. Energy Rev. 2016, 64, 749-760. [CrossRef]

37. Aidonis, D.; Achillas, C.; Folinas, D.; Keramydas, C.; Tsolakis, N. Decision Support Model for Evaluating Alternative Waste Electrical and Electronic Equipment Management Schemes-A Case Study. Sustainability 2019, 11, 3364. [CrossRef]

38. De Oliveira Neto, G.; de Jesus Cardoso Correia, A.; Schroeder, A. Economic and environmental assessment of recycling and reuse of electronic waste: Multiple case studies in Brazil and Switzerland. Resour. Conserv. Recycl. 2017, 127, 42-55. [CrossRef]

39. Riddle, A. RFID for All [review of "RFID Technology and Applications" by Miles, S.B.; Sarma, S.E.; Williams, J.R.; 2008]. IEEE Microw. Mag. 2008, 9, 176. [CrossRef]

40. Tuttle, J.R. Traditional and Emerging Technologies and Applications in the Radio Frequency Identification (Rfid) Industry. In Proceedings of the 1997 IEEE Radio Frequency Integrated Circuits (RFIC) Symposium. Digest of Technical Papers, Denver, CO, USA, 10 June 1997; pp. 5-8.

41. RFID_TAG Application. Available online: http://www.tagapplication.it/rfid/ (accessed on 28 June 2019).

42. Pantoli, L.; Leoni, A.; Stornelli, V.; Ferri, G. Energy harvester for remote sensors systems. In Proceedings of the 2016 International Multidisciplinary Conference on Computer and Energy Science (SpliTech), Split, Croatia, 13-15 July 2016. [CrossRef]

43. Leoni, A.; Pantoli, L.; Stornelli, V.; Ferri, G.; Solic, P.; Russo, M. A Combined 90/900 MHz IC Architecture for Smart Tag Application. J. Commun. Softw. Syst. 2018, 14, 27-32. [CrossRef]

44. Safraou, A.; Bacot, P.; Dudret, S.; Bourdel, E.; Granado, B. RF Harvesting Circuit for Batteryless Connected Sensor. In Proceedings of the Eurosensors 2017, Paris, France, 3-6 September 2017; p. 583. [CrossRef]

45. Yang, L.; Rida, A.; Vyas, R.; Tentzeris, M.M. RFID tag and RF structures on a paper substrate using inkjet-printing technology. IEEE Trans. Microw. Theory Tech. 2007, 55, 2894-2901. [CrossRef]

46. Steudel, S.; Myny, K.; Arkhipov, V.; Deibel, C.; Vusser, S.D.; Genoe, J.; Heremans, P. 50MHz rectifier based on an organic diode. Nat. Mater. 2005, 4, 597-600. [CrossRef] [PubMed]

47. Steudel, S.; Vusser, S.D.; Myny, K.; Lenes, M.; Genoe, J.; Heremans, P. Comparison of organic diode structures regarding high-frequency rectification behavior in radio-frequency identification tags. J. Appl. Phys. 2006, 99, 114519. [CrossRef]

48. Subramanian, V.; Frechet, J.M.J.; Chang, P.C.; Huang, D.C.; Lee, J.B.; Molesa, S.E.; Murphy, A.R.; Redinger, D.R.; Volkman, S.K. Progress towar development of all-printed RFID tags: Materials, processes, and devices. Proc. IEEE 2005, 93, 1330-1338. [CrossRef]

49. Tecnologia / Smart Res. Available online: https://www.smartres.eu/tecnologia/ (accessed on 28 June 2019).

50. Thi Thu Nguyen, H.; Hung, R.-J.; Lee, C.-H.; Thi Thu Nguyen, H. Determinants of Residents' E-Waste Recycling Behavioral Intention: A Case Study from Vietnam. Sustainability 2019, 11, 164. [CrossRef] 
51. Shevchenko, T.; Laitala, K.; Danko, Y. Understanding Consumer E-Waste Recycling Behavior: Introducing a New Economic Incentive to Increase the Collection Rates. Sustainability 2019, 11, 2656. [CrossRef]

52. Isernia, R.; Passaro, R.; Quinto, I.; Thomas, A. The Reverse Supply Chain of the E-Waste Management Processes in a Circular Economy Framework: Evidence from Italy. Sustainability 2019, 11, 2430. [CrossRef]

53. Cordova-Pizarro, D.; Aguilar-Barajas, I.; Romero, D.; Rodriguez, C.A. Circular Economy in the Electronic Products Sector: Material Flow Analysis and Economic Impact of Cellphone E-Waste in Mexico. Sustainability 2019, 11, 1361. [CrossRef]

54. Kouhizadeh, M.; Sarkis, J.; Zhu, Q. At the Nexus of Blockchain Technology, the Circular Economy, and Product Deletion. Appl. Sci. 2019, 9, 1712. [CrossRef]

55. Yang, S.; MR, A.; Kaminski, J.; Pepin, H. Opportunities for Industry 4.0 to Support Remanufacturing. Appl. Sci. 2018, 8, 1177. [CrossRef]

56. Schindler, R. Smart Trash; RAND Corporation: Santa Monica, CA, USA, 2012; pp. 20-22.

57. White, R.; Nelken, P. Transnational Environmental Crime; Taylor and Francis: Florence, Italy, 2013; pp. 19-110.

58. Bisschop, L. Governance of the Illegal Trade in e-Waste and Tropical Timber: Case Studies on Transnational Environmental Crime Lieselot Bisschop Green Criminology Series; Routledge: Ashgate, UK, 2016; ISBN 147241540X.

(C) 2019 by the authors. Licensee MDPI, Basel, Switzerland. This article is an open access article distributed under the terms and conditions of the Creative Commons Attribution (CC BY) license (http://creativecommons.org/licenses/by/4.0/). 